EIS 13/2019

Brand Recognition of the Tex Mex Products in Latvia

Submitted 06/2019

Accepted for

publication 10/2019

\section{Brand Recognition of the Tex Mex Products in Latvia}

leva Brence, RISEBA University of Applied Sciences, Latvia

Juris Bogomazovs, RISEBA University of Applied Sciences, Latvia

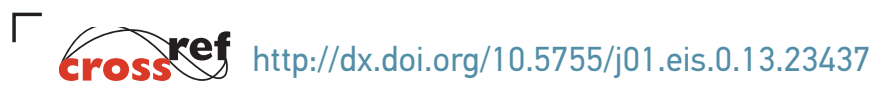

The foundation of successful business relies on recognition and positive experience among customers. The article examines theory of the brand and how well it is recognized in the Latvian spice market, focusing on the Tex Mex production. There are numerous research papers on the brand management, yet no significant research has been devoted to the Tex Mex production branding. The research in this field is important as the Latvian spice market is still growing and many different brands are offered by various manufacturers therefore the competition is tough and it is important to strengthen the market space of Tex Mex spices. Moreover, there is an increase in the European spice market, therefore the research results are important for the European spice market in general.

The purpose is to examine theoretical aspects of the brand and to evaluate the Tex Mex products' brand recognition in Latvia.

The research novelty lays in the fact that a survey of 1011 Latvian residents is used, by analyzing their habits in Latvian spice market and, expecially the Tex Mex products.

The paper contains following research methods: theory analyses; document analyses and analysis of a survey involving A 1011 Latvian residents - 454 females and 557 males, age group 15-74.

The key results of the research: compared to the previous year, customers' attitude to the products of the brand Santa Maria Tex Mex has increased and currently Santa Maria is the market leader in Latvian Tex Mex products. At the same time more than half of Latvia's people have never purchased Tex Mex products.To promote the visibility of the Tex Mex products, product tastings should be chosen as they provide further information to consumers.

KEYWORDS: brand management, brand recognition Tex Mex products, food marketing, buying habits

Branding has become a self-evident issue without which it is hard to imagine a successful product or service on the market.

The brand expresses certain functional and emotional values of a product or idea. Its mission is to be recognized, to build trust, to assert status, to guarantee quality, to intuitively let you know what users will receive. The better the brand performs these tasks, the greater the value of the brand and its owner. The company owns a brand, but its value is not found in the company itself - it is in the minds of consumers (Riezebos, 2003).

Both in Latvia and worldwide, the market is saturated with food from various manufacturers, including producers of various spices and food additives, of which the large and influential market participant is Santa Maria, a food producer, which is part of the Paulig Group.

Santa Maria is known in Latvia since 1994, when AS Paulig Baltic established its representative office in Latvia with its sales and marketing team. Since then, the situation has changed every 
year in a positive direction. The market has increasingly seen products from different origins and manufacturers, contributing to healthy competition in the food market. This fact showed that the development strategy developed by the company is correct and the brand "Santa Maria" is delicious for Latvian consumers and its products are needed.

At the same time competition is growing and there are many market-entrants. Nevertheless, not all the inhabitants still know about the Tex Mex production. Therefore a research is necessary on analysing the Tex Mex products recognition in Latvia.

Purpose: to examine theoretical aspects of the brand and to evaluate the Tex Mex products' brand recognition in Latvia.

Tasks: 1. Analyze theoretical approaches to corporate brands, methods to promote their visibility, as well as the basic conditions for strategy development; 2 . Analyze the inhabitants' opinions on the brand recognition of the Tex Mex brand; 3. Draw conclusions, suggestions.

The research methods - theory analysis, document analysis, analysis of a survey involving A 1011 Latvian residents - 454 females and 557 males, age group 15-74. To guarantee all the necessary conditions of a representative sample, a market research company "Latvijas fakti” was contracted for perforning the research.

The key results of the research: compared to the previous year, customers' attitude to the products of the brand Santa Maria Tex Mex has increased and currently Santa Maria is the market leader in Latvian Tex Mex products. At the same time more than half of Latvia's people have never purchased Tex Mex products.To promote the visibility of the Tex Mex products, product tastings should be chosen as they provide further information to consumers.

Various authors have defined different brands in different sources of literature (Aaker, 1991, Batey, 2008, Clifton, 2010, De Chernatony, \& Riley, 1997, Meldahl, 2018, etc). One of the oldest brand definitions explains the following: word, term, sign , a symbol, a design or a combination thereof designed to identify goods or services to sellers or a group of sellers and to distinguish them from competitors (De Chernatony \& Riley F. D, 1997). Nowadays the importance of the brand has become much more complex and complicated, so the brand definitions are so different and ambiguous nowadays.

The brand's mission is to be recognized, to build trust, to assert status, to guarantee quality, to intuitively let the consumer know what it will be (Brauns, 2007). Most of the brands are branded, so in the world, brand promotion is generally focused on product, service sales, or higher ranking. Brand value changes the price of a product (Cheverton, 2002), brand is a set of meanings (Batey, 2008). The brand is even one that does not belong to the company or its owner - the brand is a common sensory experience that the customer has created from any kind of contact with your company and its product or service (Hammonds, 2008). Strong brands arise only when the joint activity of the company's fundamental forces, combined with a unified strategy, penetrates all aspects of the company's business and takes over all the company's contacts (Frolova, 2006). If the brand image gets a good reputation and recognition, then the company has a chance to grow rapidly (Хейг, 2003).

Although much is said about the fact that nowadays people choose a brand not a specific product or service, the achievements still do depend on the product or service itself, its characteristics. Market specificity is what determines the brand's relationship with the company at several levels:

1 In the informative sense, brands still have a traditional role to play - to represent a product or service, inform about their market and allow to assess buyers' responses to sales and other market indicators; 
2 Brands are a sign of corporate ethics, policies, lifestyles, environmental protection, attitudes to personnel and the personality of a business manager, such as Bill Gates and Microsoft (Manternach, 2013).

Brand value is the degree of the company's brand value; this indicator may be related to financial, strategic and management benefits (Riezebos, 2003). Recognition characterizes brand value. Brand recognition and popularity are virtually synonymous. Brand recognition is more than brand recognition (Sicco, 2003).

Before talking about brand recognition one needs to understand the current place of the brand or where a new brand might come. This can be clarified by various methods. There are two types of methodology to determine brand value - based on quantitative data and qualitative data (Ellwood, 2002).

Successful brands have two characteristics: brand vitality and brand stature. Each of them consists of two more features. The brand has a brand viability when it is different from other brands in the customer's mind, and this distinction applies to the customer's needs. The brand is worthy if it inspires respect and is known in the target market (Kotlers, 2007).

If a company and its brand are market leaders and, if not, its managers can make their own brand assessment, which can be subjective, but at the same time can mark brand failures or problems.

To create a brand, one first needs to define it. To define brand, you needs to develop a brand strategy. To get a successful brand strategy, you first need to explore market trends and your potential customer needs (Meldahl, 2018).

Creating a brand first requires basic guidelines to understand where to start and how to lead it to the end. Olins has developed various guidelines, but they are too fragmented. The more transparent version of the guidelines is:

1 Brand Audit - Assessment of the brand's market situation and the perspective to develop a unified brand development concept - product, market, communication, attitude, e.g. how the cars' markets are evaluated. Design is valued - what feelings are formed when sitting or driving, how much, how much fuel does the neighbors think, seeing the car standing at the door, etc.? Brand audit is needed both for existing brands on the market to assess the current situation and for new brands before they are developed to determine the most successful brand positioning on the market (Olins, 2005).

2 Elaborating the core values of brands using a methodology for developing new or existing core values for brands, where guidelines are created for the image of the company characterising the essence, goals and ideology of the company's operations. The core values of the brand serve as a basis for creating a marketing and communication package for the company and its products. Brand guidelines determine the company's personality, operating policy, and how the company communicates with its customers. The company can fully identify with the brand (corporate approach), such as NOKIA, or the brands can be different ("back-up approach") i.e. - a number of brands, each with its own identity, but buyers look at them as a whole, such as the Elvi store network in Latvia. It is also possible to create brands where each brand unit is offered to the buyer in completely different ways. There are several more guidelines based on quality, difference, etc. (Olins, 2005).

Before one start branding, it's important to differentiate who wants to build a brand, since there are several brand levels and the resulting strategies:1)product branding; 2)line branding; 3)range brand strategy; 4)umbrella branding; 5)source brand strategy; 6)endorsing brand strategy; 7) mixed approaches (Келлер, 2016). 
Quality is a significant determinant of price premium, but adding other image dimensions doubles the predictability and understanding about price premium. The strongest determinants of price premium are social image, uniqueness and home country origin. Other significant determinants are corporate social responsibility (CSR) and awareness (Anselmsson, Vestman Bondesson, Johansson, 2014).

The global food industry is changing in ways that require even the most seasoned and skilled food manufacturers to rethink their long-term strategy (Gehlhar, et.al., 2009).

There has been a sharp increase in new food product introductions globally since the late 1990s for major branded food categories. However, little is known about the motivation behind product innovation or new product introductions (Gehlhar, et.al., 2009).

Growing consumer sophistication for convenient, healthy, environmentally friendly foods are creating greater segmentation in global food markets. Mass production is being replaced with mass customization (Gehlhar, et.al., 2009).

The Tex-Mex label has been used for at least four decades to brand all Mexican-American food. But the term has also faced confusion and disagreement over how it should be applied (Ray Wheaton, Carrollb, 2017). The core issue is "whether Tex-Mex means Americanized Mexican food in general or specifically the kind from Texas" (Walsh, 2004, quoted by Ray Wheaton, Carrollb, 2017).

There are different particularities for branding different products and institutions. Development of Santa Maria brand in Latvia, one of the main spice production wholesalers in Latvia is analysed in the next chapter.

Santa Maria is one of Europe's leading brands in the spice and food additives sector and one of the most important food exporters in Sweden. Santa Maria, originally a family business, is now a pan-European spice company with a headquarters in Melndale, Sweden, with around 850 employees. $80 \%$ of Santa Maria's shares belong to the Finnish food conglomerate Paulig Coffee, which has played a particularly important role in coffee, various national cuisine and spices. The plants are located in Sweden, Denmark, Estonia, Belgium and Holland. Santa Maria AB has long been the leading brand in the Nordic countries, found in markets in over 35 European countries, including Poland, the Baltic States, Ireland, Holland, Germany, Switzerland and Russia. And the strategy for the future is clear. Santa Maria should become Tex Mex (Mexican Cuisine) spice and product supplier no. 1 in Europe. In Northern Europe, Santa Maria continues to increase its market share in the Thai and Indian spices segment (Santa Maria, www.santamariaworld.com, 2018).

Some facts about the origins of Santa Maria brand in Latvia and its development are as follows. In 1992 Paulig Group established a branch of the company AS Paulig Baltic opened the first Santa Maria spice factory in Estonia and Saues. In 1994, AS Paulig Baltic started selling Santa Maria spices in Latvia. On December 5, 2002, a representative office of AS Paulig Baltic in Latvia was established to provide marketing support for the brands of Santa Maria and Paulig. Following market trends and growing market demand, AS Santa Maria was founded in Estonia at the end of 2006 and a representative office of AS Santa Maria in Latvia dealing with brand development was established on 21 November 2006 (Santa Maria, www.santamariaworld.com, 2018).

Santa Maria spices are one of the key concepts and are the leading brand in the Nordic market. The assortment consists of almost 100 different spices and is the basis for all the spices found in other concepts.

Santa Maria TEX MEX is the leading assortment of Mexican spices and products in the Nordic countries as well as in other European countries with its wide range of treadmills, cakes, spices, salsa sauces, corn chips and many other products. The Tex Mex concept was introduced
Historical development of "Santa Maria" brand in Latvia and recognition of Santa Maria Tex Mex products in Latvian market 
in 1991 and quickly achieved great success (Santa Maria, www.santamariaworld.com, 2018). Santa Maria BBQ is the leading and most popular grilled food assortment in the Nordic market, such as marinades and sauces. Santa Maria's offer is the key to success for anyone who wants to become a true grilling master (Santa Maria, www.santamariaworld.com, 2018).

Santa Maria ASIA is an assortment of exotic flavors unique to Thailand. This concept was introduced in the market in 2001 and was a great success. With these products, everyone can easily and quickly make Thai dishes that have become popular since Thailand has become a popular travel destination (Santa Maria, www.santamariaworld.com, 2018).

Santa Maria INDIA is the latest addition to national kitchen concepts, and one can find everything you need to prepare Indian cuisine quickly and easily. Santa Maria's fresh herbs are an assortment of fresh, ecologically cultivated herbs and potted greens (Santa Maria, www.santamariaworld.com, 2018).

The brand is an idea and it is important because the notions define the attitudes and actions of the population. The first point of contact with the brand is the name by which people identify a particular product or service, and this is undoubtedly of great importance in creating a brand image. Brand value comes from the position it occupies in the minds of people, it must be true and fulfill its promises. So brand recognition and how people value it, who is in the minds of people, and it's not easy to measure it accurately.

Quantitative data - brand recognition is determined by surveys that reveal the extent to which the brand, its logo, offer, individuality and awareness of its competitors are known to consumers. Brand recognition is also reflected in the company's sales data compared to its competitors.

In order to evaluate Santa Maria Tex Mex products brand recognition in Latvia, a survey was organised in cooperation with one of the leading market research companies in Latvia. A total of 1011 Latvian residents were surveyed, of whom 454 were women and 557 men in age group 15-74.

Table 1

Respondents answer have no idea what to cook at home therefore looking for ideas in the store(survey performed by Latvijas fakti, 2018)

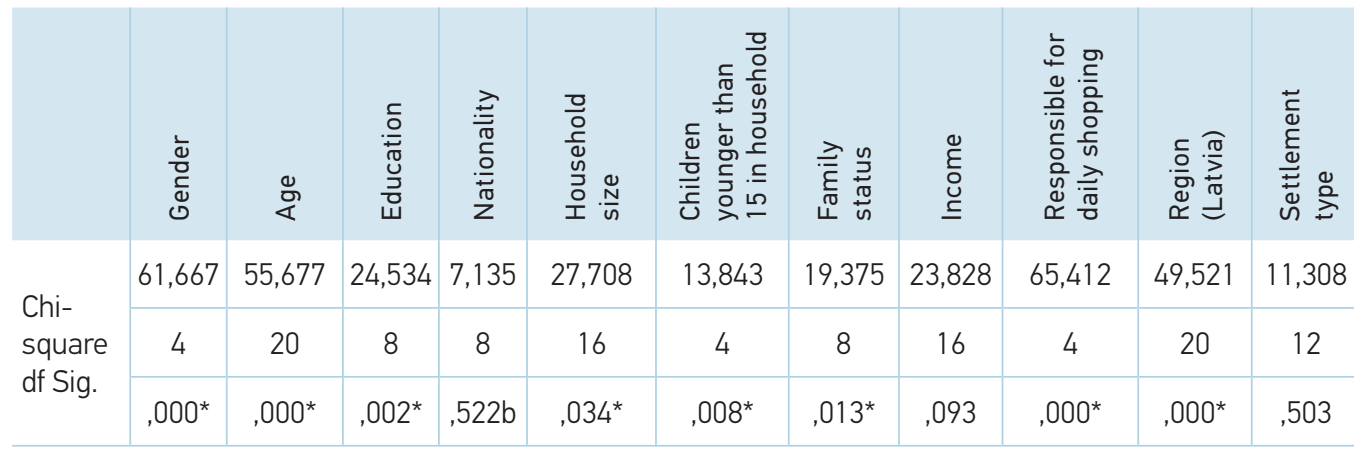

The research started with the question of whether the respondent has ever purchased any of Tex Mex's products as a possible response by respondents. The survey results report that $59.8 \%$ of the respondents have never bought Tex Mex products. Only $29.6 \%$ of respondents have purchased Tex Mex products over the past year and more $10.6 \%$ of Tex Mex products surveyed have bought more than 12 months ago. The breakdown by age group as the respondents' answers split is reflected in table 1. The results of the survey suggest that most Tex Mex products, over the last year, are purchased by consumers aged 15-34, purchasing 50\% of the 182 respondents in the 15-24 age group and Tex Mex products in the 25-34 age group. acquired $45.1 \%$ of 195 respondents. Respondents' answers suggest that the least Tex Mex products are purchased by age groups 55-64, accounting for $9.6 \%$ of 157 respondents and $65+$ years $2.9 \%$ of 138 respondents. 


\begin{tabular}{|c|c|c|c|c|c|c|c|c|c|c|}
\hline & \multirow{2}{*}{$\begin{array}{l}\text { Total } \\
1011\end{array}$} & \multicolumn{2}{|c|}{ Gender } & \multicolumn{6}{|c|}{ Age } \\
\hline & & & $\begin{array}{l}\text { Male } \\
(454)\end{array}$ & $\begin{array}{c}\text { Females } \\
(557)\end{array}$ & $\begin{array}{l}15-24 \\
(182)\end{array}$ & $\begin{array}{l}25-34 \\
(195)\end{array}$ & $\begin{array}{l}35-44 \\
(162)\end{array}$ & $\begin{array}{l}45-54 \\
(176)\end{array}$ & $\begin{array}{l}55-64 \\
(157)\end{array}$ & $\begin{array}{c}65+ \\
(138)\end{array}$ \\
\hline \multirow{3}{*}{$\begin{array}{l}\text { Have } \\
\text { you ever } \\
\text { bought } \\
\text { Tex Mex } \\
\text { products? }\end{array}$} & $\begin{array}{l}\text { Yes, in the last } \\
12 \text { months }\end{array}$ & $29,6 \%$ & $27,8 \%$ & $31,1 \%$ & $50,0 \%$ & $45,1 \%$ & $36,2 \%$ & $23,9 \%$ & $9,6 \%$ & $2,9 \%$ \\
\hline & $\begin{array}{l}\text { Yes, more than } \\
\text { one year ago }\end{array}$ & $10,6 \%$ & $28,0 \%$ & $29,0 \%$ & $22,5 \%$ & $30,3 \%$ & $28,8 \%$ & $33,0 \%$ & $35,6 \%$ & $20,3 \%$ \\
\hline & $\begin{array}{l}\text { No, have never } \\
\text { bought }\end{array}$ & $59,8 \%$ & $44,2 \%$ & $39,9 \%$ & $27,5 \%$ & $24,6 \%$ & $35,0 \%$ & $43,1 \%$ & $54,8 \%$ & $76,8 \%$ \\
\hline
\end{tabular}

Table 2

Respondents answers on the Tex Mex production buying habits (survey performed by Latvijas fakti, 2018)

Table 3

Respondents answers on the Top of mind TOM (survey performed by Latvijas fakti, 2018)
Analyzing data by age groups, one can find the greatest popularity of Santa Maria brand products in the age group 25-34, accounting for $80 \%$ of 195 respondents. $70.3 \%$ of the 182 respondents in the 15-24 age group also named the Tex Mex products of the brand Santa Maria. More information included in table 4.

\begin{tabular}{|c|c|c|c|c|c|c|c|c|c|c|}
\hline & \multirow{3}{*}{$\begin{array}{l}\text { Total } \\
1011 \\
53,4 \%\end{array}$} & \multicolumn{2}{|c|}{ Gender } & \multicolumn{6}{|c|}{ Age } \\
\hline & & & \multirow{2}{*}{$\begin{array}{l}\text { Male } \\
(454) \\
46,3 \%\end{array}$} & \multirow{2}{*}{$\begin{array}{c}\text { Females } \\
(557) \\
59,2 \%\end{array}$} & \multirow{2}{*}{$\begin{array}{l}15-24 \\
(182) \\
70,3 \%\end{array}$} & \multirow{2}{*}{$\begin{array}{l}25-34 \\
(195) \\
\\
80,0 \%\end{array}$} & \multirow{2}{*}{$\begin{array}{l}35-44 \\
(162) \\
62,0 \%\end{array}$} & \multirow{2}{*}{$\begin{array}{l}45-54 \\
(176) \\
45,5 \%\end{array}$} & \multirow{2}{*}{$\begin{array}{l}55-64 \\
(157) \\
33,8 \%\end{array}$} & \multirow{2}{*}{$\begin{array}{c}65+ \\
(138) \\
15,9 \%\end{array}$} \\
\hline \multirow{8}{*}{$\begin{array}{l}\text { Total } \\
\text { recognition } \\
\text { of TexMex }\end{array}$} & Santa Maria & & & & & & & & & \\
\hline & Virtuosso & $19,0 \%$ & $17,0 \%$ & $20,6 \%$ & $28,0 \%$ & $27,7 \%$ & $26,4 \%$ & $14,8 \%$ & $8,3 \%$ & $3,6 \%$ \\
\hline & Poco Loco & $15,1 \%$ & $11,5 \%$ & $18,1 \%$ & $22,5 \%$ & $24,1 \%$ & $23,3 \%$ & $10,8 \%$ & $3,2 \%$ & $2,2 \%$ \\
\hline & Mission & $10,6 \%$ & $8,1 \%$ & $12,6 \%$ & $14,3 \%$ & $16,9 \%$ & $13,5 \%$ & $8,5 \%$ & $4,5 \%$ & $2,9 \%$ \\
\hline & Rainbow & $10,4 \%$ & $9,3 \%$ & $11,3 \%$ & $15,9 \%$ & $14,9 \%$ & $16,6 \%$ & $8,0 \%$ & $3,2 \%$ & $0,7 \%$ \\
\hline & $\begin{array}{l}\text { Yufka } \\
\text { Mamulleri }\end{array}$ & $9,0 \%$ & $7,7 \%$ & $10,1 \%$ & $14,8 \%$ & $18,5 \%$ & $12,9 \%$ & $1,7 \%$ & $2,5 \%$ & \\
\hline & Wanted & $7,0 \%$ & $7,7 \%$ & $6,5 \%$ & $9,9 \%$ & $8,2 \%$ & $13,5 \%$ & $7,4 \%$ & $1,3 \%$ & \\
\hline & El Sabor & $7,0 \%$ & $5,7 \%$ & $8,1 \%$ & $11,5 \%$ & $11,3 \%$ & $9,8 \%$ & $4,5 \%$ & $1,9 \%$ & $0,7 \%$ \\
\hline
\end{tabular}

Table 4

Respondents answers on the total recognition of the Tex Mex brands (survey performed by Latvijas fakti, 2018) 
Table 5

Resondents answers on planning the daily purchases (survey performed by Latvijas fakti, 2018)

Table 6

Resondents answers on the Tex Mex most popular product brand (survey performed by Latvijas fakti, 2018)
Respondents were also asked on their habits planning the daily purchases. Data analysis conclude that the older the person, the more often it makes a shopping list. In the age group of 15-24 years, $37.8 \%$ of 182 respondents make the list of purchases, while in the age group 55 - 64 the total number of 157 respondents is $61.2 \%$. In the age group 65 and over, the list of purchases is made by approximately $70 \%$ of the 138 respondents. More information included in the table 5 .

\begin{tabular}{|c|c|c|c|c|c|c|c|c|c|c|}
\hline & Total & \multicolumn{2}{|c|}{ Gender } & \multicolumn{6}{|c|}{ Age } \\
\hline & & 1011 & $\begin{array}{l}\text { Male } \\
(454)\end{array}$ & $\begin{array}{c}\text { Females } \\
(557)\end{array}$ & $\begin{array}{l}15-24 \\
(182)\end{array}$ & $\begin{array}{l}25-34 \\
(195)\end{array}$ & $\begin{array}{l}35-44 \\
(162)\end{array}$ & $\begin{array}{l}45-54 \\
(176)\end{array}$ & $\begin{array}{l}55-64 \\
(157)\end{array}$ & $\begin{array}{c}65+ \\
(138)\end{array}$ \\
\hline \multirow{3}{*}{$\begin{array}{l}\text { Are you } \\
\text { planning } \\
\text { your daily } \\
\text { purchases? }\end{array}$} & Mostly yes & $52,2 \%$ & $39,7 \%$ & $62,1 \%$ & $37,8 \%$ & $42,2 \%$ & $54,3 \%$ & $54,1 \%$ & $61,2 \%$ & $69,9 \%$ \\
\hline & Sometimes & $33,8 \%$ & $41,3 \%$ & $27,8 \%$ & $36,7 \%$ & $44,0 \%$ & $39,4 \%$ & $34,7 \%$ & $24,7 \%$ & $16,4 \%$ \\
\hline & $\begin{array}{l}\text { No, more } \\
\text { impulse } \\
\text { driven }\end{array}$ & $14,0 \%$ & $19,0 \%$ & $10,1 \%$ & $25,6 \%$ & $13,8 \%$ & $6,4 \%$ & $11,2 \%$ & $14,1 \%$ & $13,7 \%$ \\
\hline
\end{tabular}

Analyzing respondents' responses to the most popular Tex Mex product brands by age group, it is concluded that Santa Maria's Tex Mex products are the most popular, if compared to other competitos. $48.9 \%$ of the respondents at age 15-24 mainly buy Santa Maria brand products, while Virtuosso brand products are mainly purchased by $12.6 \%$. The situation is very similar in the age grou $25-34,48.2 \%$ of respondents mainly purchase the Tex Mex products of the Santa Maria brand and $13.8 \%$ of respondents mainly buy Virtuosso brand products. More information is included in table 6 .

\begin{tabular}{|c|c|c|c|c|c|c|c|c|c|c|}
\hline & \multirow{3}{*}{$\begin{array}{l}\text { Total } \\
1011 \\
30,9 \%\end{array}$} & \multicolumn{2}{|c|}{ Gender } & \multicolumn{6}{|c|}{ Age } \\
\hline & & & $\begin{array}{l}\text { Male } \\
(454)\end{array}$ & $\begin{array}{c}\text { Females } \\
(557)\end{array}$ & \multirow{2}{*}{$\begin{array}{l}15-24 \\
(182) \\
48,9 \%\end{array}$} & \multirow{2}{*}{$\begin{array}{l}25-34 \\
(195) \\
48,2 \%\end{array}$} & \multirow{2}{*}{$\begin{array}{l}35-44 \\
(162) \\
34,4 \%\end{array}$} & \multirow{2}{*}{$\begin{array}{l}45-54 \\
(176) \\
27,3 \%\end{array}$} & \multirow{2}{*}{$\begin{array}{l}55-64 \\
(157) \\
12,1 \%\end{array}$} & \multirow{2}{*}{$\begin{array}{c}65+ \\
(138) \\
4,3 \%\end{array}$} \\
\hline \multirow{9}{*}{$\begin{array}{l}\text { What brand } \\
\text { do you buy } \\
\text { the most } \\
\text { often? }\end{array}$} & Santa Maria & & $27,3 \%$ & $33,8 \%$ & & & & & & \\
\hline & Virtuosso & $8,5 \%$ & $7,0 \%$ & $9,7 \%$ & $12,6 \%$ & $13,8 \%$ & $14,1 \%$ & $5,7 \%$ & $0,6 \%$ & $1,4 \%$ \\
\hline & Poco Loco & $6,4 \%$ & $5,5 \%$ & $7,2 \%$ & $10,4 \%$ & $9,7 \%$ & $11,7 \%$ & $3,4 \%$ & $0,6 \%$ & $0,7 \%$ \\
\hline & Mission & $4,6 \%$ & $3,5 \%$ & $5,6 \%$ & $6,6 \%$ & $9,2 \%$ & $6,1 \%$ & $2,3 \%$ & $0,6 \%$ & $1,4 \%$ \\
\hline & $\begin{array}{l}\text { Yufka } \\
\text { Mamulleri }\end{array}$ & $4,5 \%$ & $3,7 \%$ & $5,0 \%$ & $8,2 \%$ & $8,7 \%$ & $6,7 \%$ & $1,1 \%$ & & \\
\hline & Rainbow & $3,8 \%$ & $2,9 \%$ & $4,5 \%$ & $6,0 \%$ & $6,2 \%$ & $6,1 \%$ & $2,3 \%$ & $0,6 \%$ & \\
\hline & Wanted & $3,0 \%$ & $3,3 \%$ & $2,7 \%$ & $5,5 \%$ & $3,1 \%$ & $4,9 \%$ & $2,8 \%$ & $0,6 \%$ & \\
\hline & El Sabor & $2,8 \%$ & $3,3 \%$ & $2,3 \%$ & $7,7 \%$ & $2,6 \%$ & $3,1 \%$ & $1,1 \%$ & $0,6 \%$ & $0,7 \%$ \\
\hline & Cits & $1,6 \%$ & $0,9 \%$ & $2,2 \%$ & $0,5 \%$ & $2,1 \%$ & $2,5 \%$ & $1,7 \%$ & $2,5 \%$ & \\
\hline
\end{tabular}

From the 1,011 respondents surveyed, $23.1 \%$ or 234 respondents reported the Santa Mex brand Tex Mex products to be their favorite. In-depth analysis of the results from 234 respondents who mentioned Santa Maria's Tex Mex products as a favorite among age groups, $36.8 \%$ of 182 respondents were aged $15-24,35.9 \%$ of 195 respondents were aged $25-34,23.9 \%$ of 163 respondents aged $35-44$ years, $22.7 \%$ of 176 respondents aged $45-55,10.2 \%$ of 157 respondents aged $55-64$ and $1.4 \%$ of 138 respondents aged 65 and over. More information is included in table 7. 


\begin{tabular}{|c|c|c|c|c|c|c|c|c|c|c|}
\hline & \multirow{3}{*}{$\begin{array}{l}\text { Total } \\
1011 \\
23,1 \%\end{array}$} & \multicolumn{2}{|c|}{ Gender } & \multicolumn{6}{|c|}{ Age } \\
\hline & & & $\begin{array}{l}\text { Male } \\
(454)\end{array}$ & $\begin{array}{c}\text { Females } \\
\text { (557) }\end{array}$ & \multirow{2}{*}{$\begin{array}{l}15-24 \\
(182) \\
36,8 \%\end{array}$} & \multirow{2}{*}{$\begin{array}{l}25-34 \\
(195) \\
35,9 \%\end{array}$} & \multirow{2}{*}{$\begin{array}{l}35-44 \\
(162) \\
23,9 \%\end{array}$} & \multirow{2}{*}{$\begin{array}{l}45-54 \\
(176) \\
22,7 \%\end{array}$} & \multirow{2}{*}{$\begin{array}{c}55-64 \\
(157) \\
10,2 \%\end{array}$} & \multirow{2}{*}{$\begin{array}{c}65+ \\
(138) \\
1,4 \%\end{array}$} \\
\hline \multirow{9}{*}{$\begin{array}{l}\text { Which if } \\
\text { your most } \\
\text { favourite } \\
\text { brand? }\end{array}$} & Santa Maria & & $20,0 \%$ & $25,7 \%$ & & & & & & \\
\hline & Virtuosso & $2,8 \%$ & $2,4 \%$ & $3,1 \%$ & $3,3 \%$ & $5,1 \%$ & $4,9 \%$ & $1,1 \%$ & $0,6 \%$ & $0,7 \%$ \\
\hline & Poco Loco & $2,3 \%$ & $2,4 \%$ & $2,2 \%$ & $4,9 \%$ & $3,1 \%$ & $4,3 \%$ & & & $0,7 \%$ \\
\hline & Mission & $1,9 \%$ & $1,1 \%$ & $2,5 \%$ & $2,2 \%$ & $3,1 \%$ & $3,7 \%$ & $1,1 \%$ & & $0,7 \%$ \\
\hline & El Sabor & $1,3 \%$ & $1,8 \%$ & $0,9 \%$ & $3,8 \%$ & $1,0 \%$ & $0,6 \%$ & $0,6 \%$ & $0,6 \%$ & $0,7 \%$ \\
\hline & $\begin{array}{l}\text { Yufka } \\
\text { Mamulleri }\end{array}$ & $1,1 \%$ & $0,4 \%$ & $1,6 \%$ & $2,2 \%$ & $2,1 \%$ & $1,8 \%$ & & & \\
\hline & Wanted & $1,0 \%$ & $0,9 \%$ & $1,1 \%$ & $0,5 \%$ & $2,1 \%$ & $1,8 \%$ & $1,1 \%$ & & \\
\hline & Rainbow & $0,9 \%$ & $0,9 \%$ & $0,9 \%$ & $2,2 \%$ & $1,5 \%$ & $0,6 \%$ & $0,6 \%$ & & \\
\hline & Cits & $0,9 \%$ & $0,6 \%$ & $0,5 \%$ & $0,5 \%$ & $0,5 \%$ & $0,6 \%$ & $1,1 \%$ & $0,6 \%$ & \\
\hline
\end{tabular}

Table 7

Respondents answers on the most popular brand survey performed by Latvijas fakti, 2018)

1 Various authors have defined different brands in different sources of literature often adusting it with - word, term, sign, symbol, design or combination. There are various definitions, yet one harly cab find many research publications devoted to Tex Mex brand recognition.

2 Santa Maria is the market leader in Latvian Tex Mex products nad the products of Santa Maria Tex Mex are the most popular among all Tex Mex products sold in Latvia. The most popular Tex Mex brand in Latvia, known as the first or has ever been bought, or knows only by name, is the product of Sata Maria Tex Mex. Despite being the most popular brand, more than half of Latvia's people have never purchased Tex Mex products.

Aaker, D. 1991. Managing brand equity: Capitalizing on the value of a brand name. New York: The Free Press.

AC Nielsen market data. 2018. About. Retrieved April 5, 2019, from http://scandinfo.se/en/about/

Anselmsson, J., Vestman Bondesson, N., Johansson U. 2014. Brand Image and Customers' Willingness to Pay a $P$ rice Premium for Food Brands. Journal of Product \& Brand Management.

Baker , M. J. 2007. Marketing strategy and management. $4^{\text {th }}$ ed. Basingstoke: Palgrave Macmillan.

Batey M. 2008. Brand meaning. New York: Taylor \& Francis Group.

Blaits, D. 2004. Mārketings: rokasgrāmata. Rīga: Zvaigzne ABC.

Brauns, T. 2007. Zīmola filazofija. Izcili filazofi par zīmoliem. Rīga: Lietiškās informācijas dienests.

Brüggen, E., \& Willems, P. 2009. A critical comparison of offline focus groups, online focus groups and e-Del- phi. , Vol. 51 . International Journal of Market Research. https://doi.org/10.1177/147078530905100301

Cheverton, P. 2002. How Come your Brand isn't Working Hard Enough? London: Kogan Page Limited.

Clifton, R. 2010. Brands and Branding. London.

De Chernatony, L., \& Riley F. D. 1997. The chasm between managers and consumers views of brands: The experts perspectives. Journal of Strategic Marketing. https://doi.org/10.1080/096525497346811

Ellwood, I. 2002. The essential Brand Book. Over 100 techniques to increase brand value. London: Kogan Page Limited.

Farhana, M. 2012. Brand Elements Lead to Brand Equity: Differentiate or Die. Information Management and Business Review.

Frolova, L. 2006. Zīmola veidošana un vadīšana mūsdienu organizācijā. Rīga: Latvijas Universitātes raksti.

Gehlhar, M. J., Regmi, A., Stefanou, S. E., Zoumas,

\section{Conclusions}


L. 2009. Brand Leadership and Product Innovation as Firm Strategies in Global Food Markets. Journal of Product \& Brand Management.https://doi. org/10.1108/10610420910949013 zìmolu, piesaistīt klientus un klūt pamanāmam tirgū. Rīga: Lietišḳās informācijas dienests.

Hofs, K. G. 2002. Biznesa ekonomika. Rīga: Jāṇa Rozes apgāde.

Jansons, V., \& Kozlovkis, K. 2016. Mārketinga pētījumi I Teorija un prakse SPSS 20 vidē. Rīga: RTU izdevniecība.

Kapferer, J. N. 2008. The new strategic brand management. Kogan Page. Kogan Page.

Koniewski, M. 2012, October 14. http://www.research-pmr.com. Retrieved from Brand Awareness and Customer Loyalty: http://www.research-pmr. com/userfiles/file/wp/Brand-Awareness-and-Customer-Loyalty.pdf

Kotlers, F. 2007. Kotlers par mārketingu. Rīga: Lietišḳās informācijas dienests.

Latvijas fakti survey. 2018. Tex Mex Brand Recognition in Latvia.

Manternach, L. 2011. Does your brand have top of mind awareness? Corridor Business Journal.

Manternach, L. 2013. Your brand is your most valuable asset. Corridor Business Journal.

Meldahl, H. 2018, Decembris 20. BRANDING-It's more than being known by name. Retrieved from http://web.b.ebscohost.com/ehost/pdfviewer/pdfviewer?vid=7\&sid=744522f4-5392-4bef-99e1-ed2c64c10514\%40pdc-v-sessmgr01

Niedrīts, J. Ė. 2008. Mārketings. Rīga: Biznesa augstskola Turība.

Olinss, V. 2005. Par zīmolu. Rīga: Neputns.

Papinš, K. 2018, October 30. Kāpēc es saku "Brends". Retrieved from www.parbrendu.lv: http://www.parbrendu.lv/kapec-es-saku-brends/
Hammonds, D. 2008. Tava biznesa zīmols: kā vadīt

Ray Wheaton, D., Carrollb, G. R. 2017. Where did "Tex-Mex" come from? The divisive emergence of a social category. Research in Organizational Behavior. Volume 37, pp. 143-166. https://doi.org/10.1016/j. riob.2017.09.003

Riezebos, R. 2003. Brand Management. ,. Harlow: Financial Times/Prentice Hall.

Rubene, E. 2009. Mārketings. Rīga: Lietišḳās informācijas dienests.

Santa Maria. 2018, October 18. Santa Maria ASIA. Retrieved from https://www.santamariaworld. com/lv/produkti/azija/.

Santa Maria. 2018, October 18. Santa Maria BBQ produkti. Retrieved from https://www.santamariaworld.com/lv/produkti/bbq/.

Santa Maria. 2018, October 18. Santa Maria Tex Mex produkti. Retrieved from https://www.santamariaworld.com/lv/produkti/tex-mex/.

Santa Maria. 2018, October 18. www.santamariaworld.com. Retrieved from Santa Maria stāsts: https:// www.santamariaworld.com/lv/santa-maria-stasts/

Santa Maria. 2018, October 18. www.santamariaworld.com. Retrieved from Santa Maria: https:// www.santamariaworld.com

Sicco, V. G. 2003. Global Brand Strategy. Kogan Page Publishers.

Swystun, J.2007. The BrandGlossary. New York: Palgrave Macmillan. https://doi.org/10.1057/9780230626409

Zīmols, Z. 2018, October 30. Zīmols. Zīmola izveide, pozicionēšana. Retrieved from http://www.zimols. com/: http://www.zimols.com/

Келлер, К. Л. 2016. Стратегический брендменеджмент. Создание,оценка и управление марочным капиталом. Москва : Вильямс.

Темпорал, П. 2003. Эффективный брендменеджмент. Санкт-Петербург: Нева.

Хейг, М. 2003. Крупнейшие ошибки брендинга. Нева.

\section{BOGOMAZOVS JURIS}

RISEBA University of Applied Sciences

Dr.sc.administr.

RISEBA University of Applied Sciences

Fields of interests

Marketing Research; Labour Market

\section{Address}

Meza street 3, Riga, LV-1048, +371 26363506

E-mail: leva.Brence@riseba.lv
Address

Meza street 3,

Riga, LV-1048, Latvia

E-mail: leva.Brence@riseba.Iv 